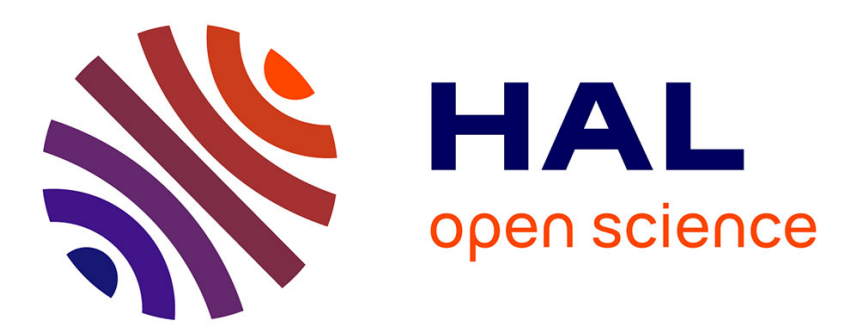

\title{
Regions and material flows: investigating the regional branching and industry relatedness of port traffic in a global perspective
}

\author{
César Ducruet, Hidekazu Itoh
}

\section{- To cite this version:}

César Ducruet, Hidekazu Itoh. Regions and material flows: investigating the regional branching and industry relatedness of port traffic in a global perspective. Journal of Economic Geography, 2016, 16 (4), pp.805-830. 10.1093/jeg/lbv010 . halshs-01145663

\section{HAL Id: halshs-01145663 \\ https://shs.hal.science/halshs-01145663}

Submitted on 1 Sep 2016

HAL is a multi-disciplinary open access archive for the deposit and dissemination of scientific research documents, whether they are published or not. The documents may come from teaching and research institutions in France or abroad, or from public or private research centers.
L'archive ouverte pluridisciplinaire HAL, est destinée au dépôt et à la diffusion de documents scientifiques de niveau recherche, publiés ou non, émanant des établissements d'enseignement et de recherche français ou étrangers, des laboratoires publics ou privés. 


\title{
Regions and material flows: investigating the regional branching and industry relatedness of port traffic in a global perspective
}

This is the pre-final version of the article published in the Journal of Economic Geography (2016), 16(4): 805-830, doi: 10.1093/jeg/lbv010

\author{
César DUCRUET \\ Centre National de la Recherche Scientifique (CNRS) \\ UMR 8504 Géographie-cités \\ 13 rue du Four, F-75006 Paris, France \\ Hidekazu ITOH \\ School of Business Administration, Kwansei Gakuin University, \\ Nishinomiya, Hyogo 662-8501, Japan
}

\begin{abstract}
This article proposes a quantitative analysis of the interdependencies between port specialization and regional specialization across the world. A global database is elaborated, covering about 360 port regions located in both developed and developing countries. One main goal is to verify how interdependent port traffic and regional characteristics are, in a context of increasingly flexible commodity and value chains. Despite the aggregated dimension of available data and the heterogeneity of local situations, the main results confirm the affinity between the primary sector and raw materials traffic, and the tertiary sector and general cargo traffic, while the industrial sector offers mixed evidence. This allows confirmation of a number of fundamental questions raised by both economic geography and regional science about transport and local development. The global typology of port regions provided in this article underlines certain regularities in their spatial distribution and discusses the policy implications of particular cases.
\end{abstract}

Keywords: material flows; maritime transport; port hinterlands; regional development JEL codes: R40; O18; L90 


\section{Introduction}

The spatial distribution and commodity specialization of physical flows in relation to the local environment where they take place remains largely unexplored and scattered across the academic spectrum. Transport studies tend to neglect the role of the socio-economic context and studies of regions rarely address transport issues. Despite the abundance of conceptual works and models integrating transport and regional development, such as in economic geography and regional science (Fujita et al., 1999; Dawkins, 2003; McCann and Shefer, 2004; Beyers and Fowler, 2012), what is lacking is a large-scale, systematic empirical investigation of the linkages between material flows and regions. More likely are studies at the national level looking at which goods are traded by which countries (Harrigan, 2004) through focusing on trade specialization and comparative advantages. A large proportion of studies at the sub-national level focus on people mobility, communication flows, transport infrastructure design, and case studies of particular cities or regions, as it will be demonstrated in the next section. Other contributions are more in the form of theoretical debates about the spatial distribution of transport and commodity chains in relation to gender and place (Leslie and Reimer, 1999), interregional inequalities, economic growth, globalization (Scott and Storper, 2003), and transnational relations and world cities (Derudder and Witlox, 2010) to name but a few. More recently, the processes of regional branching and industry relatedness have been proposed to elucidate the changing economic structure of regions, with many empirical applications to flows of labor, firms, and knowledge (Boschma and Frenken, 2011). The few existing works about material flows cover a wide array of transport modes, geographical scales, and methodologies. One objective of this paper is thus to provide an update and possible overview of existing research on regions and material flows, notably by looking at the case of port regions, as a contribution to wider debates on regional development.

While there is now concrete evidence about the positive influence of containerization on world trade (Bernhofen et al., 2013), few studies have been so systematic at the local level. As long as other transport systems did not allow sufficient connectivity, ports remained, at least until the First Industrial Revolution, essential gateways to their adjacent region so that their mutual activity developed symbiotically (Hoyle, 1989; Haynes et al., 1997). During subsequent decades, however, port activity has become more spatially concentrated and less beneficial to the local economy. Numerous factors can be identified in existing case studies, such as congestion, land scarcity, and rising cargo handling costs in large port cities resulting in diseconomies of scale and shifts of port activity towards secondary ports (Hayuth, 1981) and inland ports (Notteboom and Rodrigue, 2005). Port competition dynamics, the increasing influence of global shipping lines and terminal operators (Slack and Wang, 2002) as well as rising environmental issues in port-industrial areas accelerated such trends. In parallel, the economic benefits of port activities to cities and regions decreased gradually. The adoption of containerization implied less labor at the docks, a faster transit time for cargo handling, and increasingly bigger ships (Benacchio et al., 2000; Boske and Cuttino, 2003), while new port sites have had limited development impacts, such as transshipment hubs that captured the bulk of container traffic due to their optimal situation along major round-the-world maritime 
routes (Rodrigue and Notteboom, 2010). Yet, port studies have become more concerned by terminal operation and managerial aspects (Itoh, 2002) compared with locational aspects (Ng and Ducruet, 2014), so that comparative perspectives remain lacking.

Ports remain a rare example of a transport activity that can be measured at the local level and compared internationally in terms of the volume and composition of its traffics. The main ambition of this paper is to verify how and why certain types of port traffic are concentrated in certain types of regional economies. To elucidate this question, we constructed a global database covering nearly 1,600 ports at the level of about 360 sub-national entities located in 41 countries where equivalent socio-economic data was available, in both the developed and developing world. Problems of assigning port traffic to relevant geographical units are discussed, given the impossibility of knowing the importance of ports in total regional freight movements and overall economic development, and conversely, the importance of the regional economy for total port activity and hinterland supply chains. The remainder of this paper is organized as follows. Section 2 reviews the existing theoretical and empirical research about material flows and regional development. Section 3 introduces the database and methodological choices serving a global analysis of port-region linkages. The core of the paper lies in Section 4, which combines several statistical analyses of current port-region interdependencies across the world. Lastly, Section 5 provides a discussion and concluding remarks concerning the main outcomes of this research and its contribution to knowledge and practice.

\section{Material flows and regional development}

\subsection{General approaches}

The empirical study of material flows in relation to their local environment has attracted the attention of few works across very diverse schools of thought. One example is urban ecology, whose ambition is to measure the metabolism of cities and regions based on a detailed knowledge of all physical flows (Rees, 1992; Decker et al., 2000), with recent applications to port areas (Cerceau et al., 2014). A more classic approach focuses on the impact of transport infrastructure on the intensity of trading flows (Limao and Venables, 2001; Duranton et al., 2014) and on the location of economic activities (Holl, 2004; Lakshmanan, 2011). Applications to ports notably confirmed the importance of port infrastructure quality in enticing trade and economic development of countries (Clark et al., 2004; Kawakami and Doi, 2004; Blonigen and Wilson, 2008) and reducing manufacturing costs in local markets (Cohen and Monaco, 2008). A study by the European Commission (1999), however, concluded that there was a negative impact of ports on private investment, capital stock, and employment compared with the positive effects of roads and highways (European Commission, 1999).

Another approach focused more on the determinants of trade and traffic flows of cities and regions. Especially, some authors tested numerous determinants of regional exports in various economies, such as Poland (Cizkowicz et al., 2013) and South Africa (Matthee and Naudé, 2008), where both results suggest a positive influence of sea access on regional export 
diversity and intensity, and the United States (Bardhan and Guhathakurta, 2004) where foreign business networks rather than transport costs had a positive influence on regional exports (see also Cassey, 2011). Another recent study on Spanish regions concluded that export growth is better explained by spillovers than by the presence of port facilities in neighboring regions (Marquez-Ramos, 2014). Using graph-theoretical methods in network analysis, it was demonstrated that GDP largely explains the accessibility and centrality of cities and regions, such as for airline flows (Choi et al., 2006; Neal, 2011; Wang et al., 2011; Dobruszkes et al., 2011). Few studies have been done about on other transport modes, except from the work of Cattan (1995) on barrier effects in air and rail flows among European cities, and the one of Guerrero and Proulhac (2014) revealing distinct relationships between the French urban hierarchy and the spatial distribution of the respective export volumes of wholesalers and manufacturing companies. As seen in a study of Japan, manufacturers who produce (relatively) lower transport cost goods, or high value added goods, may decide to locate in remote areas away from consumer markets, to benefit from higher logistics accessibility (Itoh, 2014). Overall, no study has provided a more systematic evidence about the precise spatial distribution of different cargo types in relation to the socio-economic characteristics of regions.

\subsection{Port traffic}

Existing research on port regions is relatively dispersed and leads to somewhat contradictory results. Physical and functional disconnection, already addressed by spatial models of portcity evolution (Bird, 1963; Hoyle, 1989), occurs in parallel with maintained local linkages even within the same terrain of investigation. Such models depict through successive phases a gradual separation between port and city alongside major technological evolutions in the port and maritime industries, but their applicability outside the Western world was questioned due to the ability of major Asian port cities to overcome such tensions (Lee et al., 2008). First, several studies provided an empirical validation of the aforementioned models of disconnection. For example, the weakening spatial fix has been documented at the global level by looking at the decreasing correlation between the volume of port throughputs and the demographic size of port cities since the 1990s (Ducruet and Lee, 2006). At that period, container shipping companies started to adopt the hub-and-spokes network configuration just like airlines in the 1980s. This allowed them to concentrate massive traffic at certain hub ports to realize economies of scale and at the same time, drop many other ports from their services to save time and cost (Cullinane and Khanna, 1999). Port throughput volumes became evermore explained by the overall centrality of port nodes in the global shipping network, rather than a proxy for local economic activity, notably because many of these central nodes actually emerged at less-urbanized places, to avoid urban congestion and to seek for available land for expansion on greenfield sites. Such evidence confirmed previous studies on the lack of a statistical relationship between port growth and urban growth in France (Steck, 1995), the United States (De Langen, 2007), and the world (see Jacobs et al., 2010). Qualitative surveys towards shippers and forwarders about their use of local port facilities came to similar conclusions, such as McCalla et al. (2001) who found that in Canada, less 
than one third of the interviewed firms used the nearby terminal for their freight shipments and only 3 percent of the firms mentioned proximity to the terminal as a primary locational consideration, due to the greater accessibility advantage of more distant terminals. . However in Japan (Itoh et al., 2002), shippers give much importance to the location of cargo handling facilities for port choice, depending if they are on-dock, near the production plant, or elsewhere. The limited correlation between the amount of port traffic and the concentration of port and maritime firms in world cities was confirmed by Jacobs et al. (2011). Instead, their concentration tends to be in large non-port cities such as Paris and Madrid, i.e. explained it is by urban functions rather than port factors. Another type of study by geographers, more focused on employment, underlined the negative externalities of large seaports upon their host territory in the form of lower wage levels and below-average productivity compared with other regions (Grobar, 2008; Hall, 2009). This was also the case in other regions where ports mainly act as gateways serving inland core economic regions, with low - and even sometimes negative - local externalities (Jo and Ducruet, 2007), as seen with the decreasing added value of European port regions in the last few decades (Lever, 1995).

Second, another group of studies has been more interested in understanding how material flows remained tied to certain localities. For instance, the diversity of commodity traffics was found to be strongly influenced by the demographic size of port cities in the United States (Carter, 1962) and Europe (Ducruet et al., 2010). In advanced economies, container traffic growth has been lower in industrial regions than in tertiary regions (Ducruet, 2009). Across Chinese provinces, industrial productivity had a positive influence on port traffic growth (Cheung and Yip, 2011) whereas in Japan, port capital formation had significantly positive effects on GDP and private capital during 1966-1997 (Kawakami and Doi, 2004). In the same vein, Doi et al. (2001) found that technological efficiency in Japanese ports reduced the cost of shipping while forward and backward linkages of imports and exports generated positive gains in national GDP. It was also found that in China, the added value created in port areas had an important, positive impact on the outlying regional economy (Deng et al., 2013) while port investment outputs for the period 1999-2010 had uneven local impacts depending on location, stage of economic development, and land transport density (Song and van Geenhuizen, 2014). Merk et al. (2013) demonstrated that although Rotterdam and Antwerp have lesser economic impacts than Hamburg and Le Havre overall, the local linkages of the first two were stronger and notably in the petro-chemical sector, while for the latter two, impacts were better felt outside the port region, such as Paris and Bavaria. Such results also meant that even large gateways spreading containers across vast hinterlands still can maintain strong local linkages (see also Oosterhaven et al., 2001). In the same vein, Bottasso et al. (2013) concluded that in Europe, the impact of port throughput on regional employment is higher at private (or industrial) ports, but this effect is more significant when excluding liquid bulk traffic and considering service and manufacturing employment.

\subsection{Main hypotheses}


Based on the above review, what becomes clear is that the majority of existing research on port cities and regions remains bound to the connection/disconnection dichotomy about flows and spaces (see also $\mathrm{Ng}$ et al., 2014 for a useful discussion, pp. 90-91). The interdependence between port and regional activities may vary over time and across space, but the nature of their links has not yet been well explained. One main reason is that most empirical studies rely on aggregated measures of port and regional activities, which tend to blur the mutual linkages. In addition, most studies focus on containers, whereas port activities are much more diverse. Regional activity is considered in very broad terms using total population or GDP. But what is particularly lacking is a common framework that can recognize the diversity of port-region linkages, in addition to their (unidirectional) intensity or impact. To build such a framework, the following three main hypotheses can be proposed based on both regional and port studies:

H1: the volume of port traffic is proportional to regional economic activity;

$\mathrm{H} 2$ : the specialization of port traffic reflects regional economic structure;

$\mathrm{H} 3$ : the scale and scope of port traffic rests on positive regional externalities.

The first hypothesis (H1) questions the equivalence between port traffic volume and the market size of the local (or host, captive) hinterland. However, port regions serving distant core economic regions by sea and/or by land will suffer from functional mismatch: the core region attracts commodity flows while the port region remains a periphery bound to transit flows having weak ties with the local economy (Stern and Hayuth, 1984; Fujita and Mori, 1996). Ports may expand their hinterlands geographically but lose market shares in their host region, as seen in Japan (Itoh, 2013) but also in France (Ducruet, 2014) where the main markets can be served by external gateways, better connected to land and sea networks than the ones located closer to these markets. In addition, port traffic has shifted tremendously within certain countries due to changing trade routes and technological standards (Overman and Winters, 2005; Lee and Rodrigue, 2006). This raises the unsolvable issue of the spatial mismatch between port and regional economic activities, which depends on the size of port traffic and on the distance between ports and their main origin/destination markets. Core economic regions such as large port cities are more likely to suffer from congestion and lack of space, so that they will shift modern terminals to the periphery (e.g. Yangshan deep-water port in China and Laem Chabang Port in Thailand), and maintain only a limited level of port activity resting on advanced logistics functions, the rest being assumed by remote ports (see Hayuth, 1981). Port traffic is thus a composite, multi-level, and multi-location indicator mixing centrality (traffic self-generation power of the port region) and intermediacy (ability to be positioned in between various routes) (Fleming and Hayuth, 1994). This might explain why port traffic was not considered when building a composite indicator about the global competitiveness of regions (Huggins et al., 2014).

The second hypothesis (H2) focuses on the industry relatedness of specialized port traffichandled by the port region. While the link between commodity specialization and local economic specialization has been considered to be rather obvious in previous works (Haefner et al., 1980; Marti, 1985), no study has gone deeper in the analysis of possible links between 
commodity types and economic activity types. In regional science however, it was accepted that agglomeration or dispersion forces also depend on commodity specialization and regional specialization (Tabuchi and Thisse, 2002). Economic geographers demonstrated that technological relatedness among economic sectors is an important condition for regional development and innovation (Boschma and Frenken, 2011a; Neffke et al., 2011). When it comes to ports, the research framework about proximity has been discussed conceptually (Hall and Jacobs, 2010) and applied mostly to the container business in a particular region (Jacobs and Notteboom, 2011). Other works discussed why the largest ports are not always the most diversified, such as in Europe due to physical geography and the spatial pattern of hinterlands (Ducruet et al., 2010). In fact, this second hypothesis questions the "technological coherence" (Boschma and Frenken, 2011b) of port regions based on the assumption that traffics are related to local economic activities. However, there is no obvious linkage between commodity types and economic sectors a priori. While it may be assumed that any economic sector may handle any type of goods, the primary and secondary sectors should have a preference for raw materials inputs, notably since both have a tendency to agglomerate across space (Tabuchi and Thisse, 2002) while bulky flows of raw materials tend to travel shorter distances than lighter flows of manufactured goods (Guerrero, 2014). Service activities are more based on information flows and transactions, but include the transport sector itself, of which port activities and logistics, as well as retail and wholesale trade. Industrial regions are expected to have a balanced commodity profile since their basic role is to transform raw materials into finished or semi-finished products, such as petro-chemical complexes (Dunford and Yeung, 2009). Important implications for port regions might arise from the level of regional branching of port traffics, since a strong mutual port-region branching or mismatch might have either positive or negative mutual effects depending on the case; Ducruet et al. (2015) notably showed that in Europe, port regions specialized in both the industrial sector and liquid bulks traffic tend to have higher unemployment rates and lower economic outputs, while port regions specialized in both the primary sector and agricultural goods traffic are well-performing economically. The traffic specialization of ports implies the existence of specific facilities, so that not every port can handle every cargo type, and very few ports can actually handle all possible cargo types (Ducruet, 2013). Port clusters emerged in specific activities such as heavy industries in the 1960s or logistics services in the 1990s such as around major European ports and in many of the Asian free economic zones to reduce inland transport costs or foster value-added flows. In a dynamic co-evolutionary and path-dependent process which has not been studied yet, ports and regions may more or less specialize or diversify in relation to each other, but with possible time gaps between the respective adaptation to changing technological and economic cycles. The second hypothesis is thus also related to the first one (H1) as the mutual port-region specialization will vary according to the degree of geographical and functional overlap between port hinterland and port region. For instance, inland rural regions may ship their exports through a port situated in an urban region acting as the main gateway (Löfgren and Robinson, 1999).

The third hypothesis (H3) focuses on possible linkages between the scale and scope of port traffics and the vitality or well-being of the regional economy. Richer and more productive regions may be the ones more able to develop modern infrastructure and handle higher valued 
goods, as well as to technically and economically exert long-distance trades than poorer and more socially deprived regions. Since the probability for ports to handle long-distance, transit cargoes increases with their size and their level of commodity diversity, smaller ports may in general be more specialized in a few commodities (Kuby and Reid, 1992). However, the shift of modern port infrastructures towards peripheral regions to facilitate land-sea cargo transfers as well as the somewhat limited economic impact of such facilities has created a geographical and functional mismatch that is not always taken into account by regional economic theory. Ports are differentiated not only by the volume and composition (or specialization) of their traffic but also by the relative value of the handled goods and the geographic level of their connectivity. Are these values and levels place-dependent so that they depend not only on the port's own development but also on its outlying economy? As underlined empirically by Guerrero and Proulhac (2014), manufacturing activities may exhibit very distinct behavior in terms of logistics flows depending on their location and requirements. For instance, manufacturing activities located in rural areas and smaller towns "are often tributary of local inputs of raw materials (i.e. agricultural products) carried over short distances" (Guerrero and Proulhac, 2014, p. 110), while those located in medium and larger cities tend to get their inputs of materials from farther locations because of the multi-tier industries for supply chain.

\section{Methodology for a global analysis of port-region linkages}

\subsection{Defining port regions}

The concept of the port region remains vaguely defined in the literature, from a set of adjacent ports to the part of the hinterland containing the most port users for a given port (Ducruet, 2009; Itoh, 2013). In this paper, the port region refers to a sub-national administrative entity containing at least one port. One major drawback is the possible mismatch between port region and port hinterland due to the impossibility of calculating the proportion of port clients located inside the administrative region, since there is no harmonized database on port-related landward flows, especially on a global level. Port regions cannot be analyzed like functional city-regions. Official statistics never account for the share of the region in total port activity or the share of the port in total regional freight flows, especially for particular commodities and internationally, except from questionnaire surveys to shippers in certain countries such as Japan (Itoh, 2014) and France (Guerrero and Proulhac, 2014).

Methods for the more precise delineation of port hinterlands have been proposed (see a useful review by Guerrero, 2014), but they require information on landward transport accessibility and freight flows, which could not be accessed at the global level. Waterside locations, where throughput volume is measured, are not always the true origins and destinations of flows, especially given rescaling, whereby transport terminals (including ports) may in fact serve distant markets. Such flows often include transit trade via sea and/ or land linkages (e.g. coastal shipping, transshipment, distant hinterlands). Another limitation is the high heterogeneity of the land surface covered by port regions, caused by differences among national administrative systems and statistical offices. This latter problem was overcome by analyzing port-region linkages based on relative rather than absolute measures of port and 
regional activity. A good example of this complexity is given by the French case (Figure 1), for which about 50-60\% of international trade is shipped through Benelux ports. Port hinterlands rarely overlap the contours of administrative (NUTS-2) regions since they extend across inland regions for the main ports (Le Havre and Rouen for Haute Normandie, Marseilles for Provence, Antwerp for Benelux) and occupy parts of such regions for smaller ports (Nantes, Bordeaux). Even certain port regions belong to the hinterland of farther ports, such as parts of Aquitaine for Marseilles and Basse Normandie for Le Havre. Yet, the host administrative region concentrates a large share of individual port traffics, i.e. more than $65 \%$ for Haute Normandie and Provence, about 75\% for Nord-Pas-de-Calais, Pays-de-la-Loire, Languedoc-Roussillon, and more than $90 \%$ for Aquitaine, Bretagne, and Poitou.

[Insert Figure 1 about here]

Nevertheless, the use of administrative regions has also many advantages. First, it allows a simultaneous analysis of throughput specialization and regional economic specialization based on the same spatial units. Second, it encapsulates the fact that many port cities have witnessed a spatial shift of port functions towards non-urban locations, but these locations often remain in close proximity to the old urban core at a wider regional level. Third, and related with the previous, such administrative regions can be defined as the "captive" part of the hinterland, which notably contains the "port cluster", made of key actors and stakeholders forming the so-called "port community" (De Langen and Chouly, 2004). However, in some cases, it has been necessary to merge the port region with the adjacent inland region ${ }^{1}$ when both formed one single corridor. This is particularly true when the largest city and/or capital city enjoys a short-distance access and good transport connectivity to the coast.

\subsection{Measuring port and regional specialization}

Port and socio-economic statistical data used in this empirical analysis was collected for the year 2009. The resulting sample consists of 352 port regions ${ }^{2}$ including 1,587 ports located in 41 countries (Table 1), accounting for $89.7 \%$ of world port tonnage, $66.3 \%$ of world Gross Domestic Product, and 39.4\% of the world's population in 2009 (see also Figure 2). One main difficulty of this research was to access internationally comparable data on traffic and local economies (Appendix 1), which are characterized by three main categories respectively (Table 2). This level of data aggregation could not be overcome due to a lack of more detailed

\footnotetext{
${ }^{1}$ Haute Normandie and Ile-de-France (France), Valparaiso and Santiago (Chile), New South Wales and Canberra (Australia), Selangor, Kuala Lumpur, and Putrajaya (Malaysia), Maryland and Washington DC (USA), Tianjin and Beijing (China), Inner and Outer London (UK).

${ }^{2}$ From the original 352 regions, 332 were analyzed by means of correlations and factor analysis due to shortage of some variables (section 4.1), and 323 were discussed analyzed in the clustering (section 4.2) because some regions composed unique or very small clusters.
} 
(and often mismatched) statistics in many countries. ${ }^{3}$ District-level data was not fully available for city-states such as Hong Kong and Singapore, whereas larger developing countries had incomplete information on either port or socio-economic data (e.g. Argentina, Vietnam, Indonesia, and the Philippines etc.).

Traffic is measured in tons although value, rather than weight, would better underline its local impacts and linkages (Lemarchand, 2000). Three port throughput variables encompass all port activities. Solid (or dry) bulks are composed of grain, minerals, ores; liquid bulks comprise oil, gas and chemical products, and other tankers; general cargo refers to finished or semifinished goods of any kind which can be containerized or not. It must be acknowledged that containers are absorbing an increasing variety of commodities, of which bulks (Pelletier and Alix, 2004), but their true contents are not released by official statistics. Weighting traffic figures has been a necessary step in order to get closer to their broad cargo value and to better illustrate the potential employment generation power of traffics. In other words, different commodities require different types of handling facilities in ports that are more or less laborintensive. The method proposed by Charlier (1994) is one of the many "weighting rules" available in the literature, which goal is to adjust the weight of different commodities measured in tonnage to obtain more economically relevant indicators. It has the advantage to be straightforward. Crude oil and other liquid bulks are divided by 10.5 because of their usually lower value per ton and the fact that their handling at port terminals is often using pipelines and storage, thereby generating little employment. Solid bulks are divided by 6.0 and general cargo (including containers) by 2.0. To such variables were added international traffic and import traffic (tons), which are crucial indicators of the overall scope and directionality of flows including the scale of flows. More precise information on transit and transshipment, port-related firms and employment, inland modal split, physical equipment was, unfortunately, not available at such a global level for all ports. Each port variable was transformed into a ratio or index to focus more on specialization (relative) than on hierarchy (absolute). The total port traffic of regions was divided by the average port traffic of all port regions in the same continent, so as to reduce the likely bias caused by important discrepancies, for instance, between Asian and European regions. All the other port variables are location quotients (LQ), such as the share (\%) of general cargo in total regional port traffic divided by the share $(\%)$ of general cargo in total national port traffic. Although the national level may not be the best geographic scale to measure port specialization, it allows treating port activity within the context of the national transport policy and infrastructures, taking into account complementarities between port regions of the same national port system. Although 2009 is a global financial crisis year during which port traffics have undergone profound fluctuations in various regions (De Monie et al., 2011), the proposed approach based on relative scores helps to attenuate the influence of such effects on the results, since specialization indices express the longer-term and stable structures of port activity (see also Ducruet et al., 2010).

\footnotetext{
${ }^{3}$ The unemployment rate is only available for six metropolitan cities in Brazil so it was used as a proxy for state unemployment. Some Indian states were lacking socio-economic data: Lakshadweep, Andaman and Nicobar Islands, Goa, and Puducherry.
} 
[Insert Table 1 about here]

Three variables are used to measure regional socio-economic specialization based on the main economic (employment) sectors: primary, secondary, and tertiary. Complementary variables on population, unemployment rate, and productivity (Gross Regional Product, GRP) were chosen while GRP figures were harmonized in US dollars based on the World Bank database. ${ }^{4}$ The absolute demographic and economic size of regions in terms of population and GRP respectively was divided by the continental average including non-port regions just like for total port traffic. Other variables were transformed into location quotient (LQ) at national level: economic sectors, population density, GRP per capita, and unemployment rate. Such a transformation was necessary due to the fact that certain variables such as GRP per capita and unemployment rates were not directly comparable across countries, because of different social and fiscal systems. This method is widely used in urban and regional studies of economic specialization (Isard et al., 1998; Quintero, 2007). The shares (\%) of regions' traffic, population, and GRP in national totals also complement the other indicators to determine whether regions are central in their belonged economic system. Such percentages can be seen as surrogates for more complex measures of centrality in a transport and urban system, which is an essential element taken into account by more local studies of the role of transport infrastructure in local and regional economic development (McCann and Shefer, 2004). Indices based on national and continental averages thus have the advantage to take into account non-port regions, to eliminate the problem of size effects, and to allow comparability. Yet, relative scores will be influenced by the spatial pattern and distribution of national economies being more or less concentrated and/or coastal (cf. Table 1).

[Insert Figure 2 about here]

[Insert Table 2 about here]

\section{Main results}

\subsection{Global trends in port-region branching}

Comparing simple regressions between demographic size (or total population) and port throughput volumes at national and regional levels (Figure 3) confirms that the correlation increases with the level of aggregation. While $75 \%$ of port throughput is explained by demographic size at the country level, the coefficient of determination reaches only $40 \%$ at the region level due to functional and administrative biases (or much dispersion). Given the heterogeneity of the sample and the discrepancies caused by total tonnage (including

\footnotetext{
${ }^{4}$ http://data.worldbank.org/
} 
transshipment) and population figures, the significance of these results justifies further exploration of port-region linkages. Therefore, the volume of port activity still reflects the size and distribution (variety) of the local economy $(H l)$. It applies more for countries than for regions, due to logistical distortions and regional variations in terms of national transport systems and settlement patterns.

[Insert Figure 3 about here]

Correlations among our variables (Figure 4) provide interesting evidence about the overall nature of port-region linkages. The shares (\%) of port throughput, population, and GRP in respective national totals are the most correlated with each other, which corroborates the previous finding (Figure 3) about the overlap of traffic hierarchy and regional hierarchy across space, this time in relative terms (HI). Only two port variables exhibit some significantly positive correlations with regional variables, namely general cargo traffic and international traffic, both with population share, GRP share, and GRP per capita. In turn, solid bulk traffic and general cargo traffic are negatively correlated with GRP per capita and traffic share for the first and with primary sector for the second. Thus, certain (relatively) larger regions concentrate most valued (general cargo), larger scale and longer-distance traffic (international) and at the same time are richer and larger on average (H3). Although this result is based on relatively low coefficients, it indicates that not only the volume but also the nature of flows is influenced by local socio-economic characteristics. The fact that finished and semi-finished goods (general cargo) are negatively correlated with the primary sector reinforces such a fact, as agricultural activities for instance are more dispersed than other activities, and more valued traffics are thus preferably concentrated in agglomerated regions (see Combes et al., 2008 for a more general discussion). General cargo is also itself significantly correlated with traffic share, traffic share with density and international traffic, and density with the tertiary sector and international traffic but less (negative) with the primary sector (H2). Lastly, liquid bulks are significantly and positively correlated with import traffic, due to the imbalance between demand and supply of natural resources.

[Insert Figure 4 about here]

Another possibility to test the mutual influences between port and regional specialization is to compare the average concentration of throughput and employment by sector and commodity type across the world (Table 3). Regions were distinguished in terms of higher (>1) or lower $(<1)$ average specialization (of employment) in each economic sector before averaging the traffic specialization index in each traffic category, and vice-versa. Regions specialized in the primary sector are also specialized in solid bulks (1.101), but it is even more true that regions specialized in solid bulks are also specialized in the primary sector (1.151), and to a lesser 
extent in the secondary sector (1.027). This mutual effect is much higher than for other sectors/throughputs. Industrial regions and general cargo have more affinity with each other (1.027 and 1.053), while tertiary regions are more focused on liquid bulks (1.072 and 1.022) (H2). The two latter trends may be counterintuitive, due to the huge importance of combustibles for heavy industries. However, it rightfully reminds us that the service economy cannot exist without energy flows such as oil and gas (Graham, 1997), thus echoing wider debates about the underlying carrying capacity, metabolism, ecological footprint, and urban/industrial ecology of the so-called creative, knowledge economy. As recalled by Decker et al. (2000, p. 685), "Megacities are somewhat independent of their immediate environment for food, fuel, and aggregate inputs" while their consumption level depends on their size, automobile fleet, and the structure of energy production.

[Insert Table 3 about here]

This is also confirmed by a factor analysis on simple calculations applied to two sets of variables, excluding or including size variables. It provided four and six factors being above the Kaiser-Guttman rule, comprising $58.7 \%$ and $66.6 \%$ of total variance respectively, while only the four main factors are described in Figure 5 (left is excluding and right is including size variables). The position of main variables confirms the previous findings: along the first factor, solid bulks and liquid bulks concentrate at regions specialized in the primary sector, while general cargo has an opposite sign and is closer to GRP per capita, population density, and the tertiary sector (H2). Higher-valued traffics such as containers are thus much concentrated at service-oriented regions (H3). This is in line with the traditional view on cities as communication centers benefiting and generating capital-intensive infrastructure in both developed and developing countries (Scott and Storper, 2003). It also confirms the findings of Hall and Jacobs (2012) concerning the dynamic externalities provided by urban regions to port activities. Higher valued traffic concentrates in core economic regions exerting command and control functions while hosting large consumer markets (Fujita et al., 1999), despite all the physical and logistical constraints involved in the shipping of goods through these places. In addition, it is rather logical that general cargo and containers have such affinity with the tertiary sector, which includes transport activities and logistics. The handling of container flows concerns various transport modes and intermediaries as well as dedicated cargohandling infrastructures and equipments that are not available in all ports. Such results are also a clear evidence of fundamental differences between bulk materials and manufactured goods, notably in terms of their respectively low and high transportation costs (McCann and Shefer, 2004). The affinity between solid bulks and the primary sector is also explained by the fact that both have in common to remain more aggregated across space: bulk traffics travel shorter distances on average (Guerrero, 2014), while heavy industries and industries producing goods with high transport costs are more agglomerated than light industries and industries with lower transport costs (Tabuchi and Thisse, 2002). In addition, solid bulks are 
likely to contain products that are those generated by the primary sector itself, i.e. agricultural products such as grain.

In turn, the industrial sector does not show any particular affinity for specific port traffics in the first factor. Although port regions are traditionally seen as industrial regions due to the attraction of many large industrial complexes around ports, the industrial sector itself is consuming and producing various types of goods, and therefore is not logistically specialized per se. Along the second factor however, a very slight proximity exists between general cargo and the secondary sector in addition to GRP per capita ( $H 2$ and H3). Two elements motivate such a fact. Many large industrial ports have also become important logistics centers handling containers through a strategy of cargo concentration and diversification. On the other hand, manufacturing activities naturally generate important handling volumes of manufactured goods that are placed in containers, especially in developing countries such as in Asia where manufacturing plants and warehouses agglomerate near port facilities (Lee et al., 2008). Peripheral ports in Japan can attract shippers who in turn develop facilities and warehouses (Itoh et al., 2002). Perhaps, a more disaggregated analysis differentiating amongst heavy and light industries in the secondary sector (mixed evidence in this analysis) would have revealed clearer linkages with bulks and general cargo respectively. Lastly, the trend found in Table 3 about the closeness between liquid bulks and the tertiary sector is also confirmed by the second factor, where the two variables share the same sign $(H 2)$.

[Insert Figure 5 about here]

\subsection{Towards a global typology of port regions}

The nature and location of clusters for 11 variables excluding size effects (Figure 6 and Appendix 2) highlight interesting trends across the world. Six clusters of port regions are defined using non-hierarchical clustering methods: metropolitan region, industrial cluster, domestic gateway, distri-hub, peripheral, and mono-functional:

- Metropolitan regions: specialized in the tertiary sector, richer (GRP per capita) and denser but with a higher unemployment rate than the national average, these urban regions concentrate most valued traffics (general cargo) as well as energy flows (liquid bulks) and imports, while being more international. Such regions are the main gateways of their belonged economies; they constitute important consumer markets of finished goods and fossil fuels while exerting more advanced, immaterial command and control functions. Typical examples include London, Paris, New York, Tokyo, Seoul, Taipei, Shanghai, Beijing, Casablanca, Istanbul, Toronto, Santiago, etc. Most of them are often ranked among the so-called global or world cities in the related literature. A number of island regions and enclaves are also included (e.g. Baleares, Ceuta, Melilla, Corse, Canaries) due to their specialization in tourism and container flows for finished and miscellaneous goods, and the lack of industries. 
- Industrial clusters: quite comparable to the metropolitan regions as they are richer than national average and specialized in imports, international traffics, and general cargo, however, these regions differ by their specialization in the secondary sector and by lower unemployment rate and population density. Such regions have managed to attract valued traffics and extract positive impacts for the local economy. Many of these regions are important petro-chemical complexes situated in less (lower) populated environments than metropolitan regions (e.g. Antwerp, Barcelona, Bilbao, Venice, Dublin, Bergen, Louisiana, Quebec, Sao Paulo) but also manufacturing centers (e.g. Guangdong, Shandong, Fujian, Nagoya, Hamamatsu, Hampshire, Busan) having successfully combined port and local economic development and locating close to metropolitan regions.

- Domestic gateways: most of these regions have in common to be inland locations served by river or canal transport, such as in the United Stated and China, but also in Scandinavia, Turkey, Greece, and Spain. They are specialized in exports and domestic flows, solid bulks and some general cargo, with a slight specialization in the secondary (including mining) and tertiary sectors. Their main function is thus to distribute cargo locally and nationally mainly based on the local production of semi-finished goods and natural resources.

- Distri-hubs: without any specific specialization in a certain economic sector, these regions handle a majority of raw materials (solid and liquid bulks) and imports. Many of them carried a large amount of traffic overall, with examples such as Rotterdam, North Caucasian, North America's west coast, northern Brazil, and southern Italy. Because port traffics are not associated to a specific economic sector, these regions are marked by a certain logistical-territorial mismatch whereby host regions are passed through to serve other regions (or international), often inland (but also on other coasts). A substantial amount of traffics is in fact dedicated to transit trade with no link to the local economy, such as for Andalucia in Spain, Tangier in Morocco, and southern Taiwan (Kaohsiung) where large container hubs operate within dense industrial estates located far from the core of the national economy. While it may be surprising that New South Wales and Victoria in Australia fall into this category, it mostly reflects the dominance of bulks in this country and the fact that general cargo is most concentrated outside urbanized regions.

- Peripheral: very much specialized in the primary sector, with a low population density and below-average productivity (lower GRP per capita), these regions do not show any strong specialization of their port traffics, the exception being a more domestic and export profile. The fact that most French regions are included underlines the strong primacy of the capital region centered upon Paris, or mono-central country, just like for many Japanese and South Korean regions. This important category by its number of regions is another evidence of functional and spatial mismatch between port traffic and local economic structure.

- Mono-functional: only a few regions fall into this category, marked by a high unemployment rate due to lesser job opportunities, a very low productivity, a low population density, the overwhelming dominance of the primary sector and the drastic 
lack of industries (the secondary sector ranks highly negatively). These regions concentrate on North America's east coast and also in Europe (Murcia, Peloponnisos, Weser-Ems). Their traffic specialization in liquid bulks and general cargo does not seem to favor regional socio-economic welfare. It is more likely to reflect upon their high dependence on general cargo imports because of less industry.

[Insert Figure 6 about here]

\section{Conclusion}

This research has argued that contemporary spatial and functional interdependencies between ports and their host regions can only be revealed through a large-scale analysis of their respective specializations. Consequently, it has applied a variety of quantitative methods to a global database of about 1,600 ports situated in both developed and developing economies. The results have revealed significant relationships between the types of material flows and the types of port regions across the world, notwithstanding important continental and national effects in terms of the stage of development and trade vitality. The typology highlights certain strengths and weaknesses of port regions in their uneven ability to combine logistical with wider economical functions. The socio-economic difficulties of regions, such as higher unemployment levels and lower productivity, seem to be accentuated by peripherality and by disequilibrium in the traffic structure of ports. The three proposed hypotheses were, at least partially, validated by empirical findings: a large proportion of port throughputs is explained by the size of the adjacent economy; throughput specialization largely reflects local economic specialization; and core regions concentrate more valued and international traffics than peripheral regions. Yet, the spatial and functional mismatch between material flows and regional development was also evaluated for a number of regions where ports are components of local economies while serving other, often distant, regions.

The unevenness of this territorial embedding raises important policy issues and opens new research pathways. Firstly, the path-dependency of traffic specialization suggests that port development can drive regional development only under certain conditions. Reviving local economies that face important socio-economic difficulties through attracting new cargo flows might not always be a relevant option if policy makers do not consider the link with local industries. For instance, the emphasis put on containerization by numerous industrial port regions can result in negative local impacts due to the absence of specific skills and markets, while remaining a rather artificial implant bound to transit flows. Secondly, the spatial and functional mismatch between material flows and port regions, which is mainly caused by logistical improvements in both land and sea networks, shall motivate policy-makers to rethink the proximity between ports and local economies, notably in order to avoid unnecessary trucking between markets and terminals and its environmental impacts. 
Future research should be done in dynamic ways, since the current results remain static and cannot address such effects. The dynamic approach shall also verify to what extent is the diversification or specialization of port traffics path-dependent and place-dependent, i.e. in relative accordance with the evolution of the wider regional economy. More in-depth verification of such linkages may benefit from a focus on certain commodities and industries within particular economies where disaggregated data is available about both material flows and regional economic activities. Whenever possible, further research shall re-explore the possibility to analyze port regions based on a more harmonized and comparable set of spatial units. Lastly, another possible direction for further research is to analyze complementarities and similarities in the socio-economic specialization of regions connected by multiple commodity flows through maritime transport.

\section{Acknowledgements}

The authors would like to thank Mrs Liliane Lizzi from Géographie-cités for her support on cartography. They also thank Prof. Editor Neil Coe and the three anonymous reviewers for their useful comments. The research leading to these results has received funding from the European Research Council under the European Union's Seventh Framework Programme (FP/2007-2013)/ERC Grant Agreement No. [313847] 'World Seastems'. In addition, the research was supported by JSPS KAKENHI Grant Number 24730259, Japan.

\section{References}

Bardhan A.D., Guhathakurta S. (2004) Global linkages of subnational regions: coastal exports and international networks. Contemporary Economic Policy 22(2): 225-236.

Benacchio M., Haralambides H.E., Ferrari C., Musso E. (2000) On the economic impact of ports: local vs. national costs and benefits. Paper presented at the World Conference on Transport Research, Special Interest Group on Maritime Transport and Ports, Genoa, June 810 .

Bernhofen D.M., El-Sahli Z., Kneller R. (2013) Estimating the effects of the container revolution on world trade. Lund University Working Paper 2013:4, Department of Economics, School of Economics and Management.

Beyers W.B., Fowler C.S. (2012) Economic structure, technological change and location theory: the evolution of models explaining the link between cities and flows. In: Hall P.V. and Hesse M. (eds.), Cities, Regions and Flows. London: Routledge, pp. 23-41.

Bird J. (1963) The Major Seaports of the United Kingdom. London: Hutchinson.

Blonigen B.A., Wilson W.W. (2008) Port efficiency and trade flows. Review of International Economics 16(1): 21-36.

Boschma R., Frenken K. (2011a) The emerging empirics of evolutionary economic geography. Journal of Economic Geography 11(2): 295-307. 
Boschma R., Frenken K. (2011b) Technological relatedness, related variety and economic geography. In: Cooke P., Asheim B., Boschma R., Martin R., Swartz D., Tödtling F. (Eds) Handbook on Regional Innovation and Growth (Cheltenham and Northampton: Edward Elgar), pp. 187-197.

Boske L.B., Cuttino J.C. (2003) Measuring the economic and transportation impacts of maritime-related trade. Maritime Economics and Logistics 5: 133-157.

Bottasso A., Conti M., Ferrari C., Merk O., Tei A. (2013) The impact of port throughput on local employment: Evidence from a panel of European regions, Transport Policy 27: 32-38.

Carter R.E. (1962) A comparative analysis of United States ports and their traffic characteristics, Economic Geography 38: 162-175.

Cassey A.J. (2011) State foreign export patterns. Southern Economic Journal 78(2): 308-329.

Cattan N. (1995) Barrier effects: the case of air and rail flows. International Political Science Review 16(3): 237-248.

Cerceau J., Mat N., Junqua G., Lin L., Laforest V., Gonzalez C. (2014) Implementing industrial ecology in port cities: international overview of case studies and cross-case analysis. Journal of Cleaner Production 74(1): 1-16.

Charlier J. (1994) Sur le concept de tonnages pondérés en économie portuaire. Les Cahiers Scientifiques du Transport 29 : 75-84.

Cheung S.M.S., Yip T.L. (2011) Port city factors and port production: analysis of Chinese ports. Transportation Journal 50(2): 162-175.

Choi J.H., Barnett J.A., Chon B.S. (2006) Comparing world city networks: a network analysis of Internet backbone and air transport intercity linkages. Global Networks 6(1): 8199.

Cizkowicz P., Rzonca A., Uminski S. (2013) The determinants of regional exports in Poland - a panel data analysis. Post-Communist Economies 25(2): 206-224.

Clark X., Dollar D., Micco A. (2004) Port efficiency, maritime transport costs, and bilateral trade. Journal of Development Economics 75(2): 417-450.

Cohen J., Monaco K. (2008) Ports and highways infrastructure. An analysis of intra- and interstate spillovers. International Regional Science Review 31(3): 257-274.

Combes P.P., Mayer T., Thisse J.F. (2008) Economic Geography: The Integration of Regions and Nations, Princeton and Oxford: Princeton University Press.

Cullinane K., Khanna M. (2000) Economies of scale in large containerships: Optimal size and geographical implications. Journal of Transport Geography 8(3): 181-195.

Dawkins C.J. (2003) Regional development theory: conceptual foundations, classic works, and recent developments. Journal of Planning Literature 18(2): 131-172.

De Langen P.W. (2007) The economic performance of seaport regions. In Wang J.J., Olivier D., Notteboom T.E., Slack B. (eds.) Ports, Cities, and Global Supply Chains (Aldershot: Ashgate), pp. 187-202. 
De Langen P.W., Chouly A. (2004) Hinterland access regimes in seaports. European Journal of Transport and Infrastructure Research 4(4): 361-380.

De Monie G., Rodrigue J.P., Notteboom T.E. (2011) Economic cycles in maritime shipping and ports: The path to the crisis of 2008. In: Hall P.V., McCalla R., Comtois C., Slack B. (eds.) Integrating Seaports and Trade Corridors (Surrey: Ashgate), pp. 13-30.

Decker E.H., Elliott S., Smith F.A., Blake D.R., Rowland S. (2000) Energy and material flow through the urban system. Energy and the Environment 25: 685-740.

Deng P., Lu S., Xiao H. (2013) Evaluation of the relevance measure between ports and regional economy using structural equation modeling. Transport Policy 27: 123-133.

Derudder B., Witlox F. (2010) Commodity Chains and World Cities. Oxford: WileyBlackwell.

Dobruszkes F., Lennert M., Van Hamme G. (2011) An analysis of the determinants of air traffic volume for European metropolitan areas. Journal of Transport Geography 19(4): 755762.

Doi M., Tiwari P., Itoh H. (2001) A computable general equilibrium analysis of efficiency improvements at Japanese ports. Review of Urban and Regional Development Studies 13(3): 187-206.

Ducruet C. (2009) Port regions and globalization. In Notteboom T.E., Ducruet C., De Langen P.W. (eds.) Ports in Proximity: Competition and Coordination among Adjacent Seaports (Aldershot: Ashgate), pp. 43-51.

Ducruet C. (2013) Network diversity and maritime flows. Journal of Transport Geography, 30: 77-88.

Ducruet C. (2014) Les ports de l'hexagone vont-ils rester en rade ? Atlas de la France et des Français, La Vie / Le Monde, pp. 62-63.

Ducruet C., Itoh H., Joly O. (2015) Ports and the local embedding of commodity flows. Papers in Regional Science, DOI: 10.1111/pirs.12083

Ducruet C., Koster H.R.A., Van der Beek D.J. (2010) Commodity variety and seaport performance. Regional Studies 44(9): 1221-1240.

Ducruet C., Lee S.W. (2006) Frontline soldiers of globalisation: Port-city evolution and regional competition. Geojournal 67(2): 107-122.

Dunford M., Yeung G. (2009) Regional development: Port-industrial complexes. In Kitchin R., Thrift N. (eds.) International Encyclopedia of Human Geography (Amsterdam: Elsevier), pp. 285-294.

Duranton G., Morrow P., Turner M. (2014) Roads and trade: evidence from the U.S. Review of Economic Studies 81(2): 681-724.

European Commission (1999) The socio-economic impact of projects financed by the Cohesion Fund. Luxembourg: Office for Official Publications of the European Communities.

Fleming D.K., Hayuth Y. (1994) Spatial characteristics of transportation hubs: Centrality and intermediacy, Journal of Transport Geography 2: 3-18. 
Fujita M., Mori T. (1996) The role of ports in the making of major cities: Self-agglomeration and hub-effect. Journal of Development Economics 49(1): 93-120.

Fujita M., Krugman P., Venables A.J. (1999) The Spatial Economy: Cities, Regions and International Trade. MIT Press, Cambridge \& London.

Graham S. (1997) Telecommunications and the future of cities: debunking the myths. Cities 14(1): 21-29.

Grobar L.M. (2008) The economic status of areas surrounding major U.S. container ports: Evidence and policy issues. Growth and Change 39(3): 497-516.

Guerrero D. (2014) Deep-sea hinterlands: Some empirical evidence of the spatial impact of containerization. Journal of Transport Geography 35: 84-94.

Guerrero D., Proulhac L. (2014) Freight flows and urban hierarchy. Research in Transportation Business and Management 11: 105-115.

Haefner L.E., Lang D.E., Cronin T. (1980) Forecast of key commodity flows at a regional port. Transportation Research Record 763: 2-5.

Hall P.V. (2009) Container ports, local benefits and transportation worker earnings. Geojournal 74(1): 67-83.

Hall P.V., Jacobs W. (2010) Shifting proximities: The maritime ports sector in an era of global supply chains. Regional Studies 44(9): 1103-1115.

Hall P.V., Jacobs W. (2012) Why are maritime ports (still) urban, and why should policy makers care? Maritime Policy and Management 39(2): 189-206.

Harrigan J. (2004) Specialization and the volume of trade: do the data obey the laws? In: Choi E.K. and Harrigan J. (eds.) Handbook of International Trade, Oxford: WileyBlackwell, 10.1002/9780470756461.ch4

Haynes K.E., Hsing Y.M., Stough R.R. (1997) Regional port dynamics in the global economy: The case of Kaohsiung, Taiwan. Maritime Policy and Management 24(1): 93-113.

Hayuth Y. (1981) Containerization and the load center concept. Economic Geography 57(2): 160-176.

Holl A. (2004) Transport infrastructure, agglomeration economies, and firm birth: empirical evidence from Portugal. Journal of Regional Science 44(4): 693-712.

Hoyle B.S. (1989) The port-city interface: Trends, problems, and examples. Geoforum 20(4): 429-435.

Huggins R., Izushi H., Prokop D., Thompson P. (2014) The Global Competitiveness of Regions. Routledge.

Isard W., Azis I.J., Drennan M.P., Miller R.E., Saltzman S., Thorbecke E. (1998) Methods of Interregional and Regional Analysis. Aldershot: Ashgate.

Itoh H. (2002) Efficiency changes at major container ports in Japan: A Window Application of Data Envelopment Analysis. Review of Urban and Regional Development Studies 14(2): 133-152. 
Itoh H. (2013) Market area analysis of port in Japan: An application of fuzzy clustering. Proceedings of the 2013 International Association of Maritime Economists Conference (IAME), Marseilles, 3-5 July.

Itoh H. (2014) An impact analysis of logistics accessibility improvements on the productivity of manufacturing sectors. Proceedings of the $5^{\text {th }}$ International Conference on Transportation and Logistics (T-LOG), Bangkok, 28-30 July.

Itoh H., Tiwari P., Doi M. (2002) An analysis of cargo transportation behaviour in Kita Kanto (Japan). International Journal of Transport Economics 29(3): 319-335.

Jacobs W., Ducruet C., De Langen P.W. (2010) Integrating world cities into production networks: The case of port cities. Global Networks 10(1): 92-113.

Jacobs W., Hall P.V., Koster H.R.A. (2011) The location and global network structure of maritime advanced producer services. Urban Studies 48(13): 2749-2769.

Jacobs W., Notteboom T.E. (2011) An evolutionary perspective on regional port systems: The role of windows of opportunity in shaping seaport competition. Environment and Planning A 43: 1674-1692.

Jo J.C., Ducruet C. (2007) Rajin-Seonbong, new gateway of Northeast Asia. Annals of Regional Science 41(4): 927-950.

Kawakami T., Doi M. (2004) Port capital formation and economic development in Japan: A vector autoregression approach. Papers in Regional Science 83: 723-732.

Kuby M., Reid N. (1992) Technological change and the concentration of the U.S. general cargo port system: 1970-88, Economic Geography 68: 272-289.

Lakshmanan T.R. (2011) The broader economic consequences of transport infrastructure investments. Journal of Transport Geography 19(1): 1-12.

Lee J.Y., Rodrigue J.P. (2006) Trade reorientation and its effects on regional port systems: The Korea-China link along the Yellow Sea rim. Growth and Change 37: 597-619.

Lee S.W., Song D.W., Ducruet C. (2008) A tale of Asia's world ports: The spatial evolution in global hub port cities. Geoforum 39: 372-385.

Leslie D., Reimer S. (1999) Spatializing commodity chains. Progress in Human Geography 23: 401-420.

Lemarchand A. (2000) Mesures de la valeur et des emplois, emplois et valeurs des mesures : la dynamique des ports. Report for the French National Planning Agency, Paris: DATAR.

Lever W.F. (1995) Regional economic growth and port activities in European cities. Proceedings of the 5th International Conference Cities and Ports, Dakar, Senegal.

Limao N., Venables A.J. (2001) Infrastructure, geographical disadvantage, transport costs, and trade. The World Bank Economic Review 15(3): 451-479.

Löfgren H., Robinson S. (1999) Spatial networks in multi-region computable general equilibrium models. Trade and Macroeconomics Division Research Paper No. 35, International Food Policy Research Institute, Washington DC. 
Marquez-Ramos L. (2014) Port facilities, regional spillovers and exports: Empirical evidence from Spain. Papers in Regional Science, doi: 10.1111/pirs.12127

Marti B.E. (1985) Chilean ports: commodity specialization and potential for containerization, Professional Geographer 37: 320-328.

Matthee M., Naudé W. (2008) The determinants of regional manufactured exports from a developing country. International Regional Science Review 31(4): 343-358.

McCalla R.J., Slack B., Comtois C. (2001) Intermodal freight terminals: Locality and industrial linkages. Canadian Geographer 45(3): 404-413.

McCann P., Shefer D. (2004) Location, agglomeration and infrastructure. Papers in Regional Science 83(1): 177-193.

Merk O., Manshanden W.J.J., Dröes M.I. (2013) Inter-regional spillovers of seaports: The case of Northwest Europe. International Journal of Transport Economics 40(3): 401-417.

Neal Z.P. (2011) The causal relationship between employment and business networks in US cities. Journal of Urban Affairs 33(2): 167-184.

Neffke F., Henning M., Boschma R. (2011) How do regions diversify over time? Industry relatedness and the development of new growth paths in regions. Economic Geography 87(3): 237-265.

Ng A.K.Y., Ducruet C. (2014) The changing tides of port geography (1950-2012). Progress in Human Geography 38(6): 785-823.

Ng A.K.Y., Ducruet C., Jacobs W., Monios J., Notteboom T., Rodrigue J.P., Slack B., Tam K.C., Wilmsmeier G. (2014) Port geography at the crossroads with human geography: Between flows and spaces. Journal of Transport Geography, 41: 84-96.

Notteboom T.E., Rodrigue J.P. (2005) Port regionalization: Towards a new phase in port development. Maritime Policy and Management 32(3): 297-313.

Oosterhaven J., Eding G.J., Stelder D. (2001) Clusters, linkages and interregional spillovers: Methodology and policy implications for the two Dutch mainports and the rural North. Regional Studies 35: 809-822.

Overman H.G., Winters L.A. (2005) The port geography of UK international trade. Environment and Planning A 37(10): 1751-1768.

Pelletier J.F., Alix Y. (2004) Vers une nouvelle approche méthodologique pour analyser le phénomène de la conteneurisation des marchandises au Canada. Proceedings of the 39th GRTC Annual Conference, Calgary: Canadian Transportation Research Forum, Vol. 1, pp. 326-341.

Quintero J.P. (2007) Regional Economic Development: An Economic Base Study and ShiftShare Analysis of Hays County, Texas. Research Report, Texas State University-San Marcos, Dept. of Political Science, Public Administration.

Rees W.E. (1992) Ecological footprints and appropriated carrying capacity: what urban economics leaves out. Environment and Urbanization 4(2): 121-130. 
Rodrigue J.P., Notteboom T.E. (2010) Foreland-based regionalization: Integrating intermediate hubs with port hinterlands. Research in Transportation Economics 27(1): 19-29.

Scott A.J., Storper M. (2003) Regions, globalization, development. Regional Studies 37(6-7), 579-593.

Slack B., Wang J.J. (2002) The challenge of peripheral ports: An Asian perspective. Geojournal 56(2): 159-166.

Song L., van Geenhuizen M. (2014) Port infrastructure investment and regional economic growth in China: Panel evidence in port regions and provinces. Transport Policy, 36: 173183.

Steck B. (1995) Les villes portuaires dans le réseau urbain français. Proceedings of the PortCity Lifestyles Conference, 12-14 October 1994, Paris, pp. 101-111.

Stern E., Hayuth Y. (1984) Developmental effects of geopolitically located ports, in: Hoyle B.S. and Hilling D. (eds.) Seaport Systems and Spatial Change, John Wiley and Sons, Chichester: pp. 239-249.

Tabuchi T., Thisse J.F. (2002) Regional specialization and transport costs. Discussion Paper (London: CEPR).

Wang J., Mo H., Wang F., Jin F. (2011) Exploring the network structure and nodal centrality of China's air transport network: a complex network approach. Journal of Transport Geography 19(4): 712-721. 


\begin{tabular}{|c|c|c|c|c|c|c|}
\hline Country & $\begin{array}{l}\text { No. port } \\
\text { regions }\end{array}$ & $\begin{array}{l}\text { No. } \\
\text { ports }\end{array}$ & $\begin{array}{l}\text { Avg. surface } \\
\text { area }(000 \text { s sq. } \\
\text { km) }\end{array}$ & $\begin{array}{c}\text { Total port } \\
\text { throughput (million } \\
\text { metric tons) }\end{array}$ & $\begin{array}{l}\text { Share }(\%) \text { in } \\
\text { national GDP }\end{array}$ & $\begin{array}{c}\text { Administrative } \\
\text { unit } *\end{array}$ \\
\hline Australia & 7 & 39 & $1,098.5$ & 880.9 & 97.9 & State/TL2 \\
\hline Belgium & 3 & 5 & 3.0 & 202.0 & 40.5 & Province/NUTS-2 \\
\hline Brazil & 20 & 80 & 332.6 & 732.9 & 83.0 & State \\
\hline Bulgaria & 2 & 2 & 17.1 & 21.9 & 22.8 & NUTS-2 \\
\hline Canada & 10 & 90 & 940.4 & 464.0 & 80.3 & TL2 \\
\hline Chile & 11 & 19 & 58.8 & 105.9 & 43.6 & TL2 \\
\hline China & 18 & 89 & 166.9 & 8031.7 & 76.8 & Province \\
\hline Croatia & 1 & 1 & 24.7 & 19.7 & 32.0 & NUTS-2 \\
\hline Denmark & 5 & 34 & 8.6 & 81.8 & 100.0 & NUTS-2 \\
\hline Estonia & 3 & 6 & 6.3 & 34.4 & 76.6 & NUTS-3 \\
\hline Finland & 3 & 22 & 77.6 & 89.5 & 90.1 & NUTS-2 \\
\hline France & 10 & 20 & 23.6 & 298.4 & 36.4 & Région/ NUTS-2 \\
\hline Germany & 7 & 39 & 10.8 & 259.7 & 20.6 & NUTS-2 \\
\hline Greece & 11 & 25 & 10.8 & 110.9 & 96.2 & NUTS-2 \\
\hline Iceland & 2 & 40 & 51.5 & 6.2 & 100.0 & Region \\
\hline India & 12 & 187 & 116.4 & 821.1 & 60.9 & State \\
\hline Ireland & 2 & 10 & 34.2 & 40.8 & 100.0 & NUTS-2 \\
\hline Italy & 13 & 40 & 16.0 & 455.7 & 66.2 & NUTS-2 \\
\hline Japan & 39 & 172 & 8.0 & 1966.4 & 87.1 & Prefecture/TL3 \\
\hline Latvia & 2 & 3 & 7.0 & 58.9 & 63.7 & NUTS-3 \\
\hline Lithuania & 1 & 2 & 5.2 & 34.3 & 12.4 & NUTS-3 \\
\hline Malaysia & 10 & 17 & 29.3 & 380.8 & 55.4 & State \\
\hline Malta & 1 & 2 & 0.2 & 3.4 & 94.4 & NUTS-3 \\
\hline Mexico & 13 & 33 & 65.9 & 113.6 & 34.6 & State/TL2 \\
\hline Morocco & 9 & 12 & 67.9 & 71.1 & 52.9 & Province \\
\hline Netherlands & 6 & 14 & 4.0 & 482.1 & 64.7 & NUTS-2 \\
\hline New Zealand & 2 & 15 & 132.5 & 42.7 & 100.0 & Island/TL2 \\
\hline Norway & 6 & 26 & 42.4 & 145.7 & 93.9 & NUTS-2 \\
\hline Poland & 2 & 5 & 20.6 & 45.0 & 9.6 & NUTS-2 \\
\hline Portugal & 6 & 8 & 14.5 & 60.0 & 95.7 & NUTS-2 \\
\hline Romania & 1 & 3 & 35.8 & 35.2 & 10.5 & NUTS-2 \\
\hline Russia & 5 & 31 & $2,134.7$ & 496.4 & 35.3 & Federal district \\
\hline Slovenia & 1 & 1 & 8.0 & 13.3 & 56.3 & NUTS-2 \\
\hline South Africa & 3 & 8 & 130.9 & 275.2 & 37.6 & Province \\
\hline South Korea & 7 & 26 & 14.2 & 1032.1 & 100.0 & TL2 \\
\hline Spain & 12 & 28 & 18.1 & 360.7 & 65.8 & NUTS-2 \\
\hline Sweden & 8 & 30 & 51.3 & 140.4 & 100.0 & NUTS-2 \\
\hline Taiwan & 4 & 13 & 9.0 & 235.7 & 100.0 & Region \\
\hline Turkey & 14 & 51 & 24.2 & 291.1 & 73.4 & NUTS-2 \\
\hline United Kingdom & 24 & 52 & 7.9 & 489.6 & 65.8 & NUTS-2 \\
\hline United States & 36 & 287 & 165.9 & 2052.0 & 86.8 & State/TL2 \\
\hline All countries & 352 & $\mathbf{1 , 5 8 7}$ & 152.2 & 21483.2 & 66.3 & \\
\hline
\end{tabular}

Table 1: Study sample

* NUTS: Nomenclature des Unités Territoriales Statistiques (Eurostat); TL: Territorial Level (OECD) 


\begin{tabular}{|c|c|c|c|c|c|}
\hline Type & \# & Variable & Unit & Index & Name \\
\hline \multirow{7}{*}{ 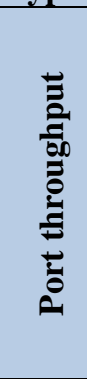 } & 1 & Total port throughput & Metric tons & $\begin{array}{l}\text { Regional weight / continental } \\
\text { average }\end{array}$ & Throughput \\
\hline & 2 & $\begin{array}{l}\text { Throughput share in } \\
\text { national total }\end{array}$ & $\%$ & $\%$ & Throughput(\%) \\
\hline & 3 & International throughput & Metric tons & Regional share / national share & International \\
\hline & 4 & Import throughput & Metric tons & Regional share / national share & Import \\
\hline & 5 & Solid bulk throughput & Metric tons & Regional share / national share & Solid_bulk \\
\hline & 6 & Liquid bulk throughput & Metric tons & Regional share / national share & Liquid_bulk \\
\hline & 7 & General cargo throughput & Metric tons & Regional share / national share & General_cargo \\
\hline \multirow{10}{*}{ 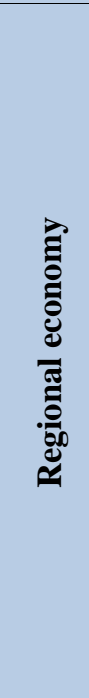 } & 8 & Population & $\begin{array}{l}\text { No. } \\
\text { inhabitants }\end{array}$ & $\begin{array}{l}\text { Regional weight / continental } \\
\text { average }\end{array}$ & Population \\
\hline & 9 & $\begin{array}{l}\text { Population share in } \\
\text { national total }\end{array}$ & $\%$ & $\%$ & Population(\%) \\
\hline & 10 & Population density & Inhab./sq.km. & Regional density / national density & Density \\
\hline & 11 & Unemployment rate & $\%$ & Regional score / national score & Unemployment \\
\hline & 12 & $\begin{array}{l}\text { Gross Regional Product } \\
\text { (GRP) }\end{array}$ & \$US & $\begin{array}{l}\text { Regional weight / continental } \\
\text { average }\end{array}$ & GRP \\
\hline & 13 & $\begin{array}{l}\text { GRP share in national } \\
\text { total }\end{array}$ & $\%$ & $\%$ & $\operatorname{GRP}(\%)$ \\
\hline & 14 & GRP per capita & \$US & Regional score / national score & $\mathrm{GRP}(\mathrm{pc})$ \\
\hline & 15 & $\begin{array}{l}\text { Employment in primary } \\
\text { sector }\end{array}$ & $\begin{array}{l}\text { No. } \\
\text { employees }\end{array}$ & Regional share / national share & Primary \\
\hline & 16 & $\begin{array}{l}\text { Employment in } \\
\text { secondary sector }\end{array}$ & $\begin{array}{l}\text { No. } \\
\text { employees }\end{array}$ & Regional share / national share & Secondary \\
\hline & 17 & $\begin{array}{l}\text { Employment in tertiary } \\
\text { sector }\end{array}$ & $\begin{array}{l}\text { No. } \\
\text { employees }\end{array}$ & Regional share / national share & Tertiary \\
\hline
\end{tabular}

Table 2: List of variables

\begin{tabular}{|c|c|c|c|c|c|c|c|c|c|c|}
\hline \multirow{3}{*}{$\begin{array}{l}\text { Economic sector } \\
\text { specialization }\end{array}$} & \multirow{3}{*}{$\begin{array}{l}\text { World } \\
\text { average }\end{array}$} & \multicolumn{9}{|c|}{ Port throughput specialization } \\
\hline & & \multirow{2}{*}{$\begin{array}{l}\text { Solid } \\
\text { bulks }\end{array}$} & \multirow{2}{*}{$\begin{array}{c}\text { Liquid } \\
\text { bulks }\end{array}$} & \multirow{2}{*}{$\begin{array}{c}\text { General } \\
\text { cargo }\end{array}$} & \multicolumn{2}{|c|}{ Solid bulks } & \multicolumn{2}{|c|}{ Liquid bulks } & \multicolumn{2}{|c|}{ General cargo } \\
\hline & & & & & $\leq 1$ & $\geq 1$ & $\leq 1$ & $\geq 1$ & $\leq 1$ & $\geq 1$ \\
\hline \multirow{2}{*}{ Primary } & $\leq 1$ & 0.959 & 1.036 & 1.020 & \multirow{2}{*}{0.882} & \multirow{2}{*}{1.151} & \multirow{2}{*}{1.027} & \multirow{2}{*}{0.966} & \multirow{2}{*}{1.134} & \multirow{2}{*}{0.815} \\
\hline & $\geq 1$ & 1.101 & 0.911 & 0.949 & & & & & & \\
\hline \multirow{2}{*}{ Secondary } & $\leq 1$ & 1.000 & 1.023 & 0.978 & \multirow{2}{*}{0.979} & \multirow{2}{*}{1.027} & \multirow{2}{*}{1.043} & \multirow{2}{*}{0.946} & \multirow{2}{*}{0.962} & \multirow{2}{*}{1.053} \\
\hline & $\geq 1$ & 1.001 & 0.973 & 1.027 & & & & & & \\
\hline \multirow{2}{*}{ Tertiary } & $\leq 1$ & 1.053 & 0.922 & 1.005 & \multirow{2}{*}{1.021} & \multirow{2}{*}{0.973} & \multirow{2}{*}{0.983} & \multirow{2}{*}{1.022} & \multirow{2}{*}{0.997} & \multirow{2}{*}{1.005} \\
\hline & $\geq 1$ & 0.959 & 1.072 & 0.983 & & & & & & \\
\hline
\end{tabular}

Table 3: Mutual port-region specialization trends 
Eurostat (Europe), American Association of Port Authorities (Mexico), Army Corps of Engineers (USA), Ports Australia (Australia), Ministry of Maritime Affairs and Fisheries (MOMAF, South Korea), Statistik Pengangkutan (Malaysia), States \& Union Territories Maritime Boards (India), Transnet (South Africa), Ministry of Land, Infrastructure, Transport and Tourism (Japan), Statistics Canada (Canada), Agência Nacional de Transportes Aquaviários (Brazil), Directemar (Chile), Statistics New Zealand (New Zealand), Agence Nationale des Ports (Morocco), Icelandic Maritime Administration (Iceland), Ministry of Transportation and Communications R.O.C. (Taiwan), Federal Maritime and River Transport Agency (Russia), China Statistical Yearbooks (China)
Sabah state 2010 (international throughput), China 2010 (all throughputs), own estimates for Iceland and New Zealand (international throughput)

\section{Regional economy (2009)}

Eurostat (Europe), OECD Territorial Database (OECD countries), Instituto Brasileiro de Geografia e Estatística (IBGE, Brazil), Ministry of Labour and Employment \& Central Statistics Office (India), Statistics Bureau, Ministry of Internal Affairs and Communications (Japan), Bureau of Statistics (USA), Institudo Nacional de Estadistica y Geografia (Mexico), Haut-Commissariat au Plan (Morocco), Statistics Iceland (Iceland), National Statistics \& Directorate-General of Budget, Accounting and Statistics (Taiwan), National Statistical Office (Malta), Statistics Lithuania (Lithuania), Central Statistical Bureau (Latvia), Statistics Estonia (Estonia), Federal State Statistics Service (Russia), National Bureau of Statistics (China)
Chile 2005, Mexico 2010, Australia 2007 (employment)

Gross Value Added (South Africa 2005; Brazil 2009), national currency (Morocco 2007; Norway 2007; Turkey 2008), average current income per household (Taiwan 2010) (GDP)

\section{Appendix 1: Sources for port and regional data}

\begin{tabular}{|l|c|c|c|c|c|c|}
\hline Variables / clusters & $\begin{array}{c}\text { Metropolitan } \\
\text { region }\end{array}$ & $\begin{array}{c}\text { Industrial } \\
\text { cluster }\end{array}$ & $\begin{array}{c}\text { Domestic } \\
\text { gateway }\end{array}$ & $\begin{array}{c}\text { Distri- } \\
\text { hub }\end{array}$ & Peripheral & $\begin{array}{c}\text { Mono- } \\
\text { functional }\end{array}$ \\
\hline PORT_International & 0,302 & 0,355 & $-0,652$ & 0,071 & $-0,164$ & 0,007 \\
\hline PORT_Import & 0,560 & 0,321 & $-1,133$ & 0,176 & $-0,205$ & 0,450 \\
\hline PORT_Solidbulk & $-0,503$ & $-0,261$ & 0,339 & 0,817 & $-0,101$ & $-1,280$ \\
\hline PORT_Liquidbulk & 0,298 & $-0,069$ & $-1,163$ & 0,626 & $-0,095$ & 0,646 \\
\hline PORT_GeneralCargo & 0,357 & 0,298 & 0,161 & $-0,954$ & 0,084 & 0,719 \\
\hline REGION_Density & 0,808 & $-0,141$ & 0,153 & $-0,034$ & $-0,459$ & $-0,989$ \\
\hline REGION_Unemp. & 0,330 & $-0,494$ & 0,056 & $-0,080$ & 0,035 & 0,639 \\
\hline REGION_GRPpc & 0,351 & 0,598 & 0,014 & $-0,090$ & $-0,428$ & $-1,494$ \\
\hline REGION_Primary & $-0,790$ & $-0,124$ & $-0,209$ & 0,017 & 0,588 & 1,648 \\
\hline REGION_Secondary & $-0,334$ & 0,656 & 0,147 & 0,062 & $-0,158$ & $-1,319$ \\
\hline REGION_Tertiary & 0,873 & $-0,554$ & 0,122 & $-0,077$ & $-0,290$ & $-0,082$ \\
\hline No. port regions & 47 & 59 & 43 & 82 & 81 & 11 \\
\hline
\end{tabular}

Appendix 2: Composition of port region clusters 


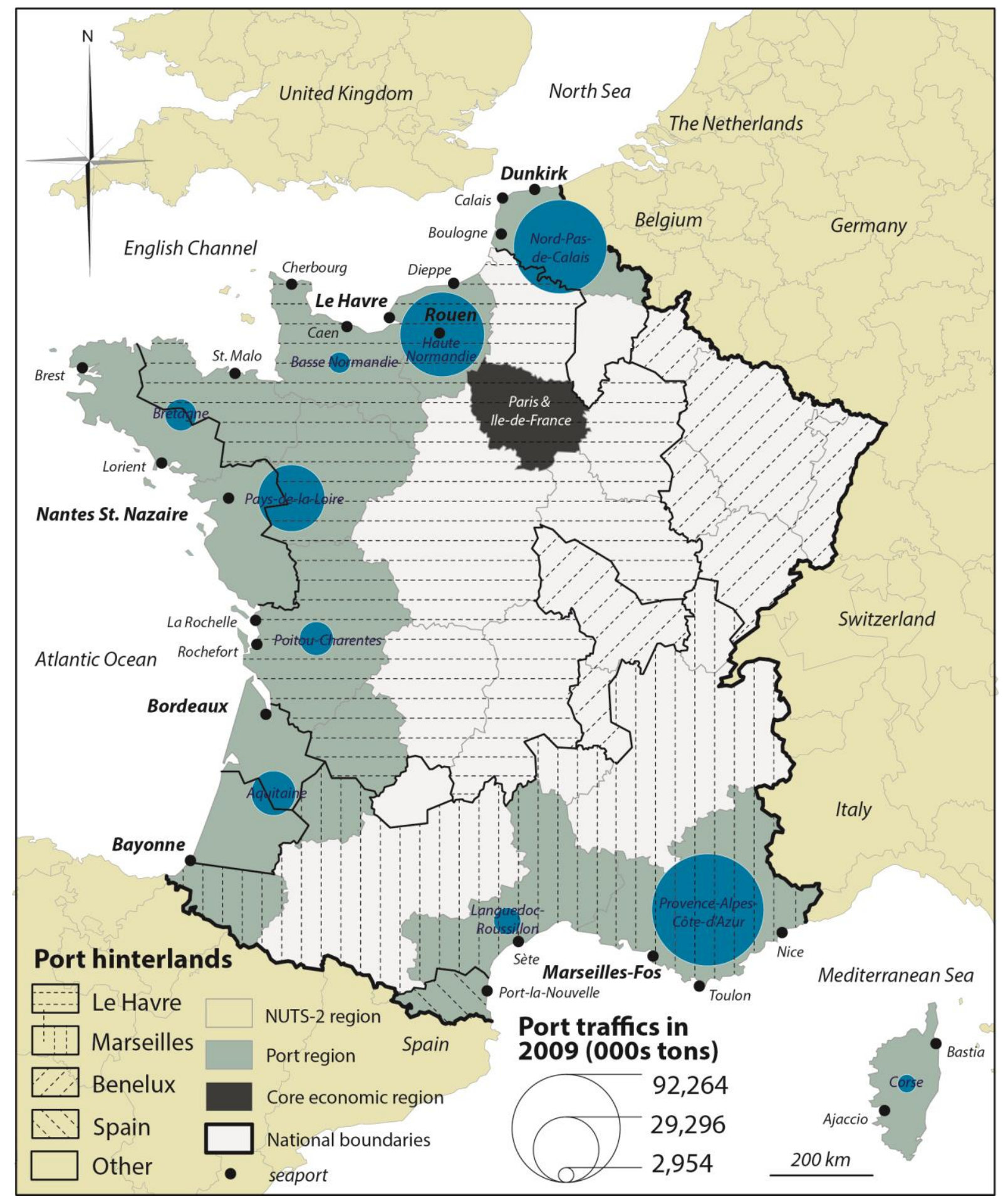

Figure 1: Port regions, hinterlands, and traffics in France

(Source: own realization based on Eurostat and Guerrero, 2014) 


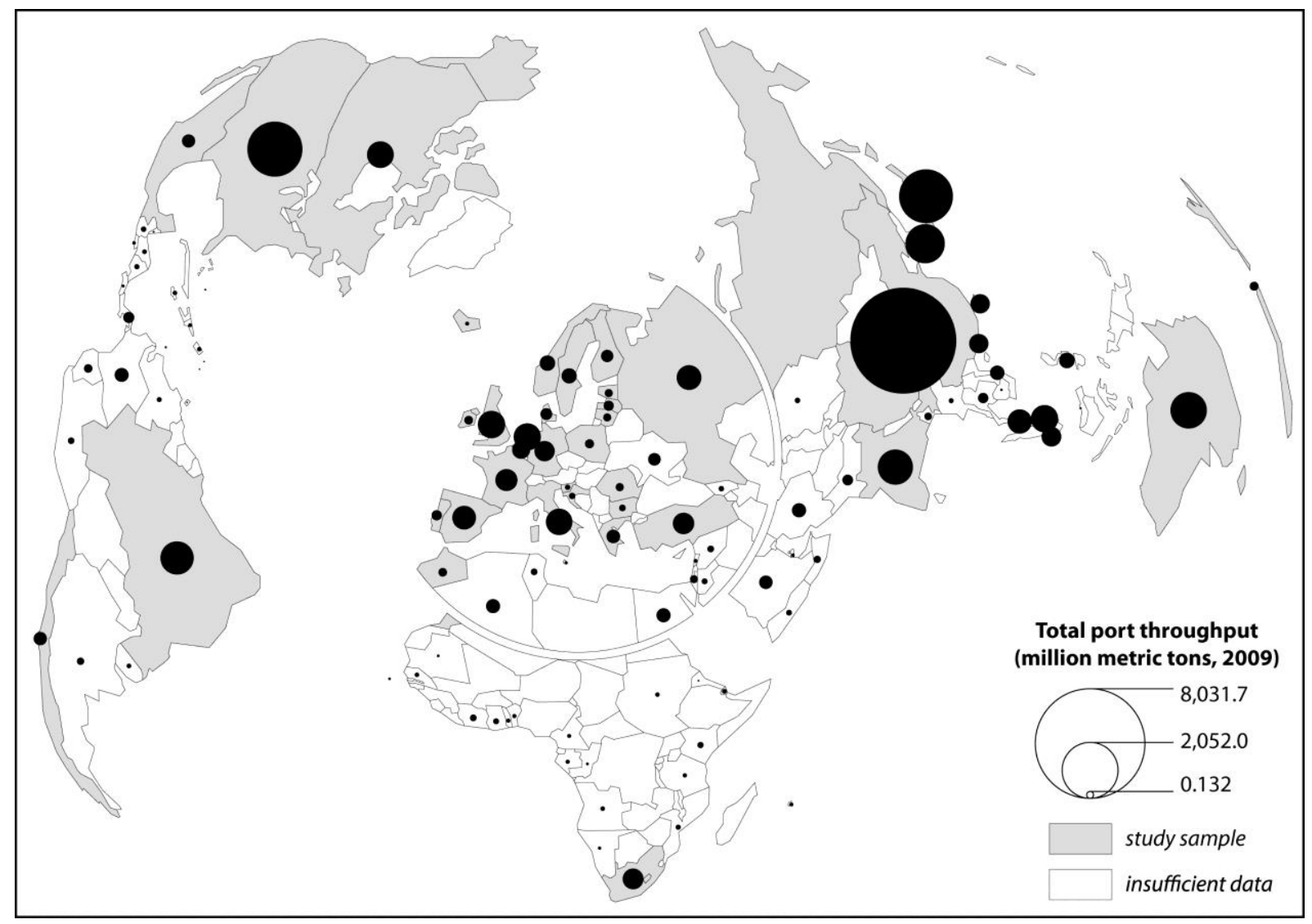

Figure 2: World port throughput by country in 2009

(Source: own realization based on various sources) 


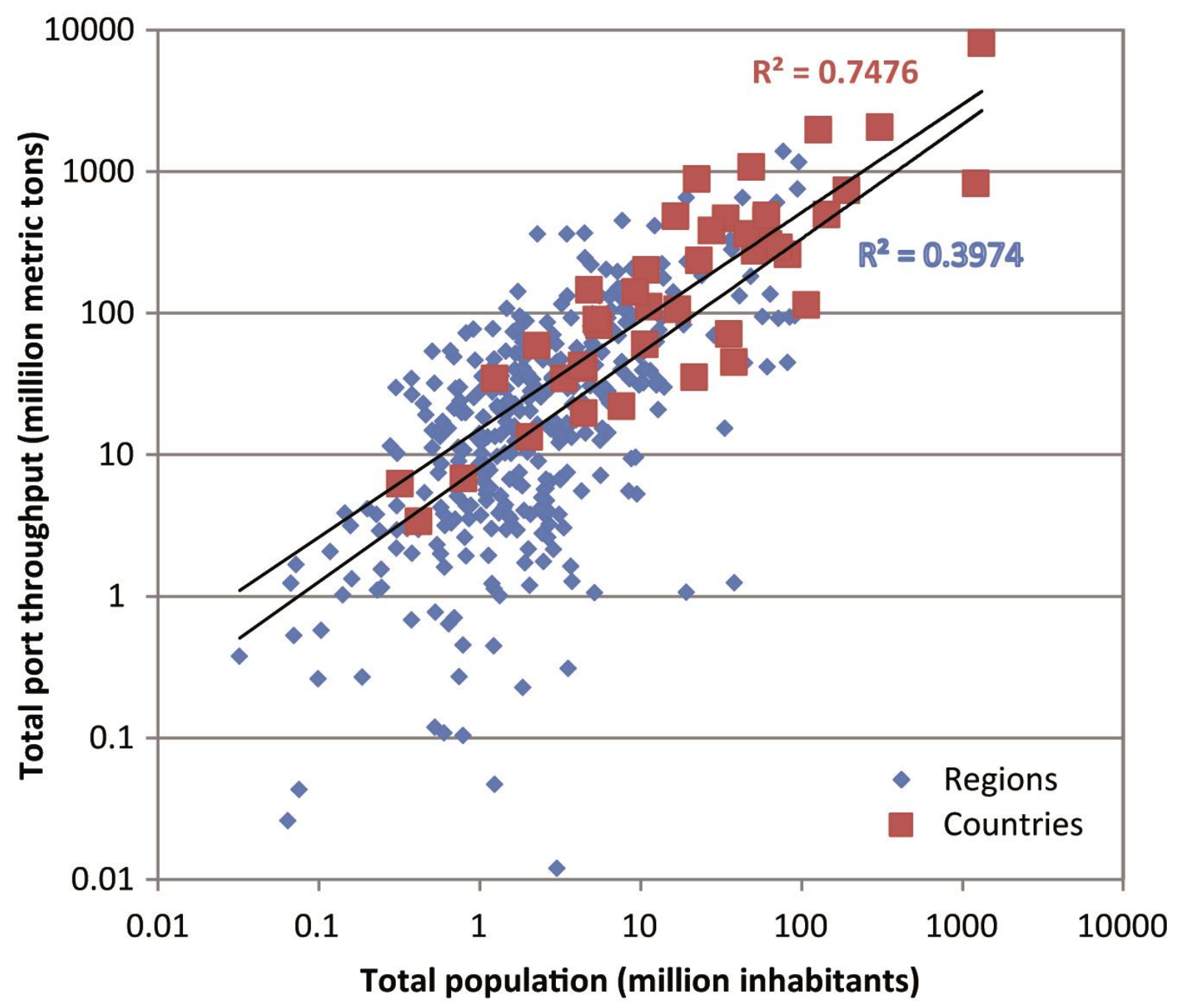

Figure 3: Population and port throughput at region and country levels

(Source: own realization based on various sources) 


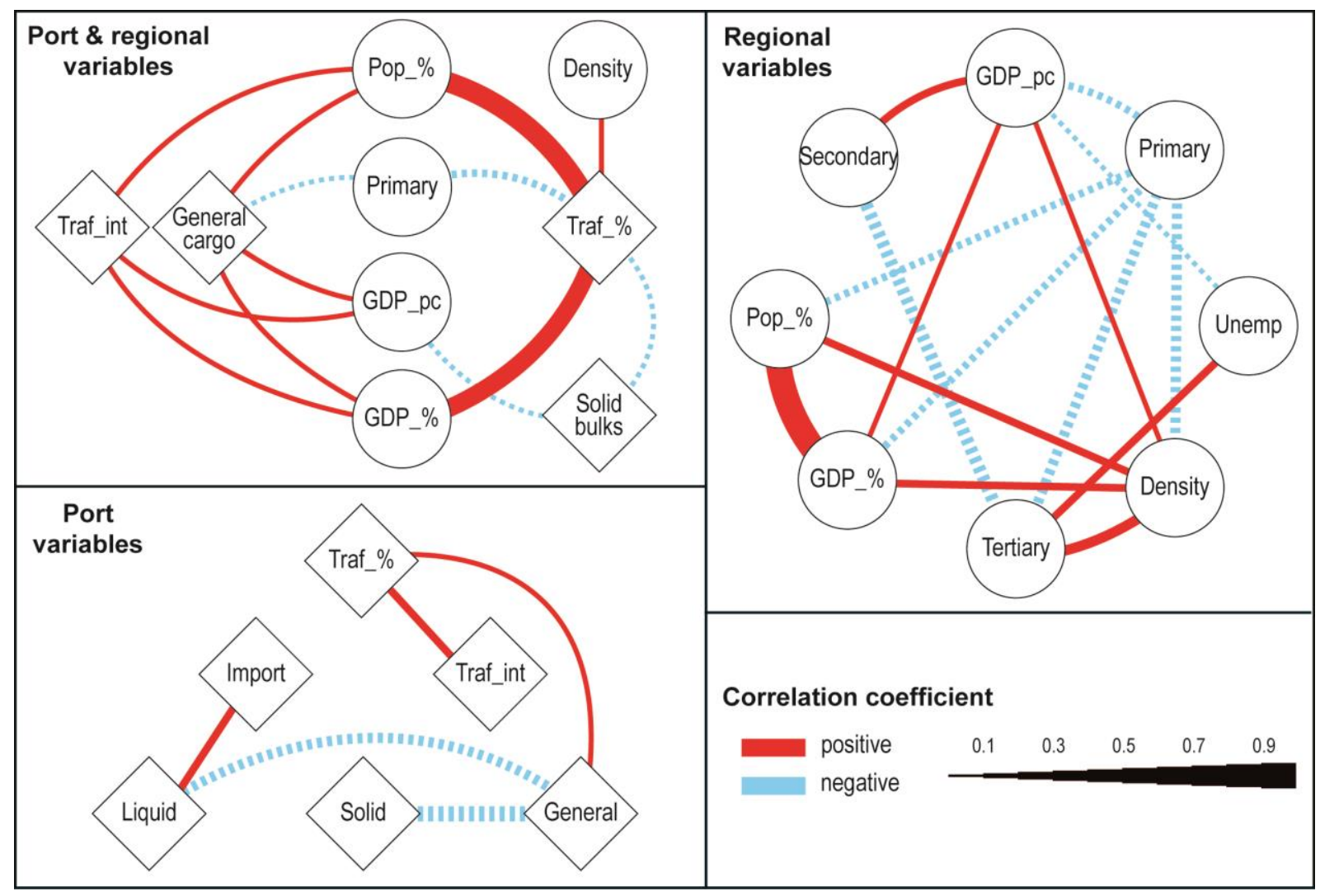

Figure 4: Correlations among main variables (1\% significance) 


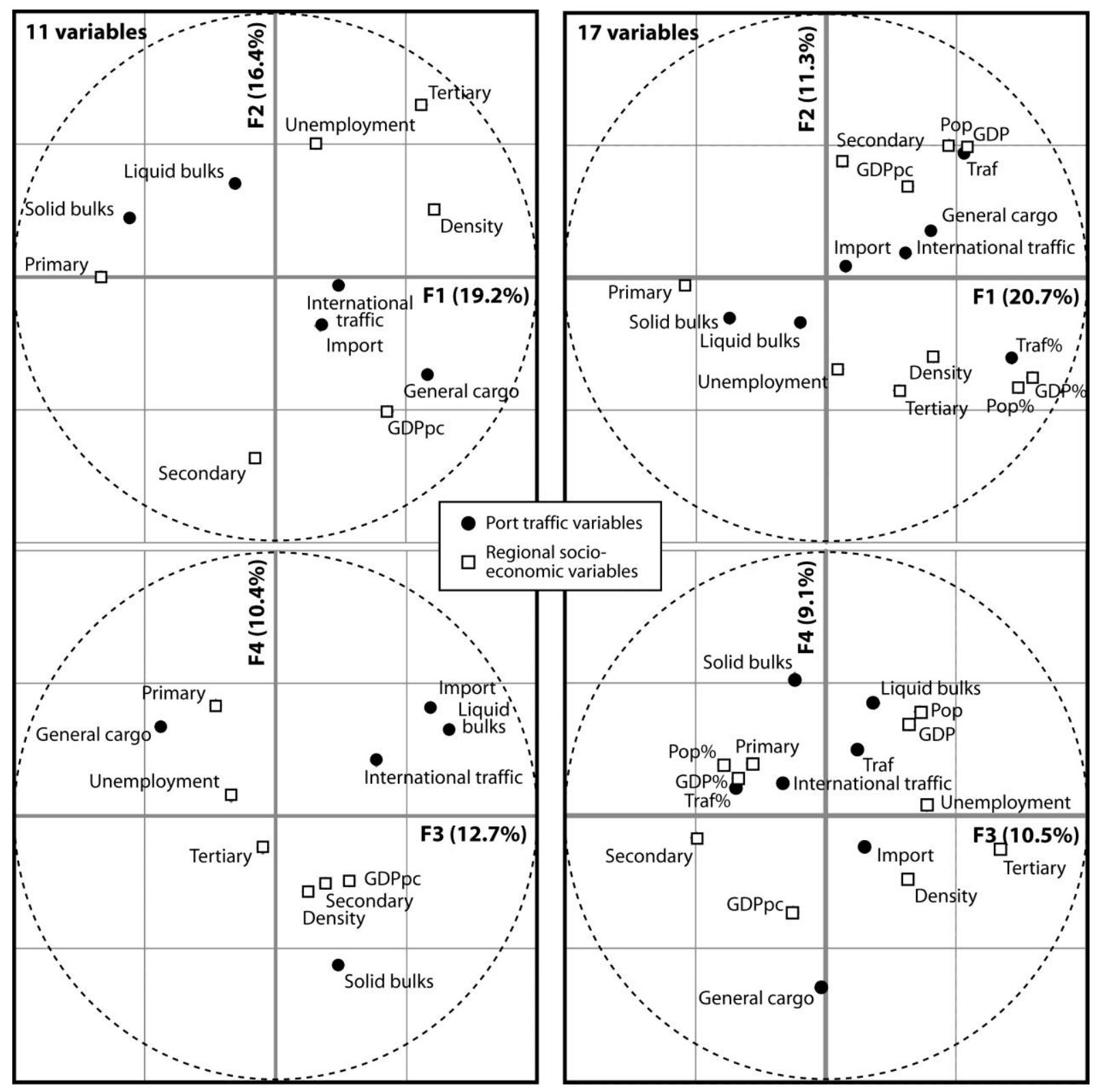

Figure 5: Main results of the factor analysis 


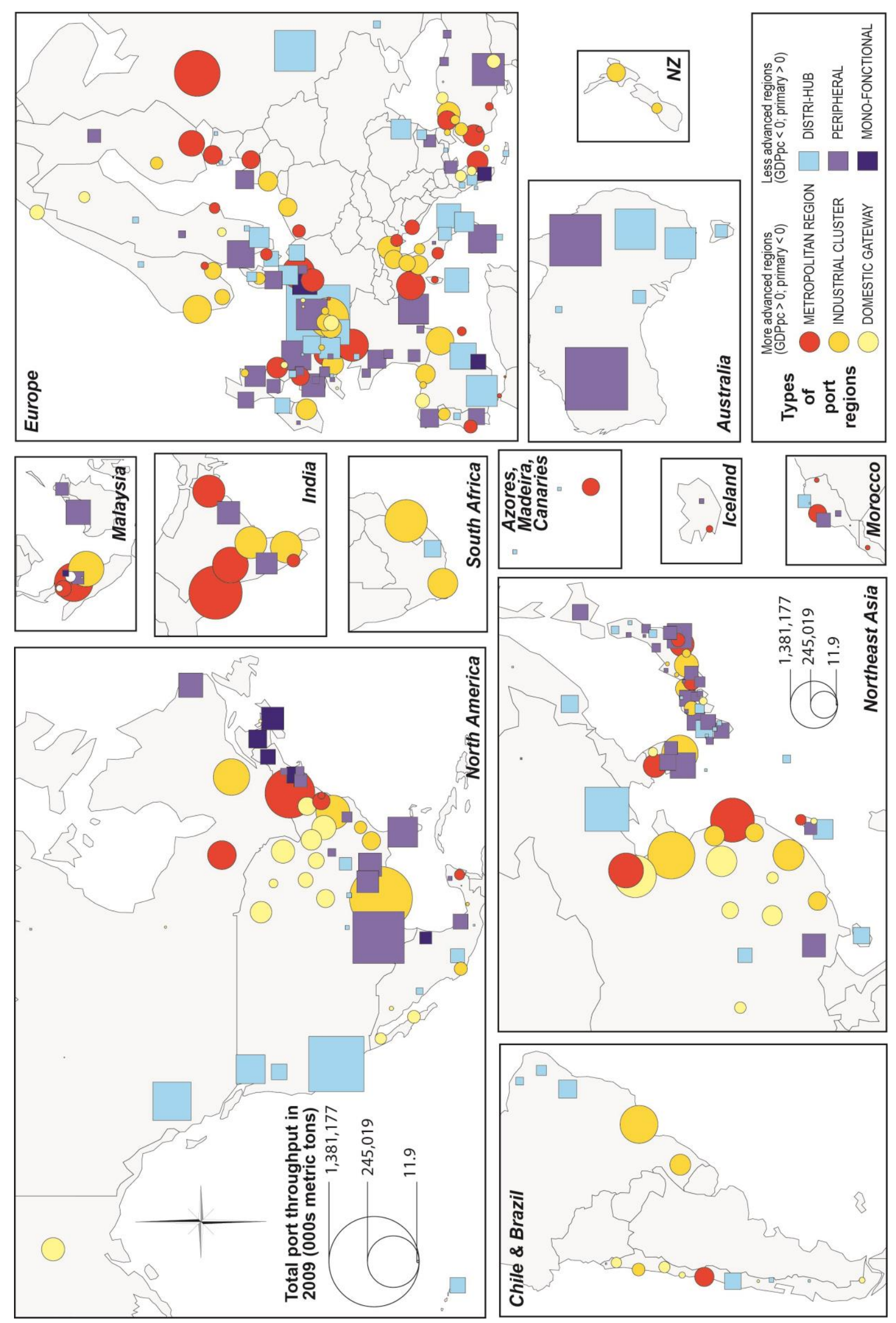

Figure 6: Global typology of port regions 